\title{
Políticas Públicas: confusão de ideias e/ou subordinação ideológica?
}

Paulo de Tarso Leite Presgrave Soares*

\section{Introdução}

Primeiramente, como é de praxe, quero agradecer ao convite para estar aqui. Vou contar como as coisas aconteceram. Um dia, recebi uma ligação do Prof. Carlos José Espíndola, o amigo Carlão, me dizendo: "Paulinho vem aqui falar sobre políticas públicas". Eu respondi que não iria, pois detesto esse tema políticas públicas, tenho horror às "besteiradas" que são ditas nesse tema, nada tinha para falar sobre isso. No dia seguinte, no entanto, estava eu ministrando uma aula sobre o neoliberalismo, usando o livro de Foucault, Nascimento da Biopolítica e, de repente, me dei conta de que o que falava atendia ao pedido do amigo Carlão. Terminada a aula, pensei mais um pouco e escrevi para ele dizendo o que eu falaria e perguntando se ele mantinha o convite. Ele respondeu que sim, e eu comecei a preparar esta apresentação, incorporando outros autores.

Descobri depois, pelo Paulo Henrique Schlickmann, que seria uma mesa com os Profs. Armen Mamigonian e José Messias Bastos. Imediatamente pensei: "Não acredito que me puseram junto do Armen e do Messias. Vou "apanhar"!". Mas, como diz o ditado paulista, não se recusa pedido de amor velho. Faz tanto tempo que somos amigos, tanto tempo que eu "apanho" deles, que o Armen me chama de reacionário e o Messias "pega no meu pé" no Facebook, eu criticando o PT e ele defendendo. Além do mais, seria ótimo rever os velhos amigos. O que eu não sabia era que ia ter essa cerimônia. Eu achei que seria em uma sala de aula, conversando com os alunos. Sempre que há essa pompa, eu fico

Professor da FEA/USP.

Geosul, Florianópolis, v. 29, ESPECIAL, p 117-142, jul./dez. 2014 
SOARES, P.de T.L.P. Políticas Públicas: confusão de ideias e/ou ...

um pouco nervoso, intimidado, como estou agora. Meu jeito coloquial não combina com cerimônias. Mas vamos lá! ${ }^{1}$

Qual a intenção desta apresentação? É fazer uma provocação. Quem me conhece sabe que sou um provocador nato. Tem muita gente defendendo as teses neoliberais sem saber o que elas de fato significam. Então eu pergunto: "Isso é uma confusão de ideias e/ou uma subordinação ideológica?”. Quero também dar uma "dica" de porque o PT está prestes a perder a eleição. Essas são as provocações. Eu sou um suicida mesmo, pois vim falar essas coisas em um ninho da esquerda petista.

Vou começar este texto pelo discurso clássico, liberal, que legitima a propriedade privada, o Estado e o mercado. Depois, vou discutir sumariamente a destruição desse discurso, levada a cabo por Marx e completada por Lenin. Posteriormente, vou sumariar o keynesianismo e expor mais detalhadamente o pensamento neoliberal. Na parte final, vou, primeiramente, fazer uma crítica ao neoliberalismo numa perspectiva marxista-leninista-lukacsiana e, depois, vou criticar essa ideia de políticas públicas, encerrando com o que me parece uma iminente derrota eleitoral do $\mathrm{PT}^{2}$.

${ }^{1}$ Eu não imaginava que a exposição seria publicada e a fiz de forma bem coloquial, usando algumas vezes até mesmo um linguajar chulo. Exposições coloquiais não costumam gerar textos legíveis e, neste caso, não gerou mesmo. Isso ficou evidente quando recebi a transcrição para análise. Para transformar aquela transcrição em um texto legível, publicável, retirei as expressões chulas, cortei as repetições, expliquei melhor alguns pontos, corrigi certas omissões e mudei de lugar certos pontos. Também coloquei algumas referências imprescindíveis, de forma que o leitor interessado tem o autor e o título da obra e assim consegue encontrá-la.

${ }^{2}$ Dilma Roussef venceu as eleições, mas foi uma vitória tão apertada que não invalida o que eu disse, especialmente porque ela não teve maioria na parte mais rica do país, com a derrota espetacular no estado mais rico. Foi uma luta entre ricos e pobres? Claro, mas em São Paulo muitos pobres não votaram nela. Subordinação ideológica? Sim! Esse é o ponto a que chamei a atenção na palestra, especialmente como o PT, um partido de direita, vem contribuindo para isso. 
SOARES, P.de T.L.P. Políticas Públicas: confusão de ideias e/ou ...

$* * *$

Qual é o discurso burguês clássico, que vai de Grotius e Hobbes a Adam Smith, legitimando a propriedade privada, o Estado e o mercado? Uma parte dos liberais diz que o homem é egoísta e aquisitor, porém com o atributo da razão. A propriedade privada, o Estado e o mercado são a combinação daquelas características, produzindo uma superação daquele estado original do homem. Esse é um discurso que naturaliza e, por conseguinte, eterniza aquelas instituições. Se as instituições burguesas são expressões da natureza humana, elas são eternas. Estamos, portanto, condenados a sobreviver sob as condições da propriedade privada, do Estado e do mercado.

Já outro discurso burguês diz que a razão só informa o que é certo e errado, que ela não induz à ação, que esta é induzida pelo sentimento moral e que a simpatia talvez seja o mais importante sentimento moral. A troca é uma expressão do sentimento moral da simpatia. Troca-se para agradar ao outro. A troca, o mercado e, consequentemente, o Estado e a propriedade privada que ele garante, estão em consonância com a natureza do homem. Tem-se, dessa forma, outro modo de dizer que estamos condenados a sobreviver sob as condições da propriedade privada, do Estado e do mercado.

Marx fez a crítica a esse discurso. Se o homem tem algo como uma natureza, algo como uma essência, ela é irrelevante para explicar esse homem, o que é o mesmo que dizer que o homem não tem natureza, não tem uma essência. Assim, Marx rompe a ligação entre a natureza humana, a propriedade privada, o Estado e o mercado. Como Marx rompe essa ligação?

Afirmando que o homem não tem uma natureza, Marx diz que o que nos torna humanos é o trabalho, pois somente o homem produz sua vida mediante o trabalho. Os animais produzem sua vida de acordo com sua condição genética, programados geneticamente. As abelhas, as formigas não trabalham, pois não têm antecipadamente na mente o objeto da sua ação ao produzir a 
SOARES, P.de T.L.P. Políticas Públicas: confusão de ideias e/ou ...

vida. Elas agem por instinto. A abelha e a formiga produzem suas vidas do mesmo jeito há milênios, mas nesse período o homem alterou espantosamente o modo como ele produz sua vida. Animais adaptam-se ao meio ambiente, mas o homem muda o próprio meio ambiente que, por sua vez, muda o homem. A vida do homem é produzida segundo a maneira como ele interage com outros homens e com a natureza que o rodeia. Se é assim, se o homem não tem uma natureza, uma essência, propriedade privada, Estado e mercado não podem expressar algo que não existe. $\mathrm{O}$ capitalismo, portanto, pode sim ser substituído por outro modo de produção da vida.

Mais ainda, diz Marx. Se a produção da vida é feita mediante o mercado, mediante a divisão social do trabalho na forma capitalista, essa produção da vida é a degradação da vida. Degradação da vida porque o trabalho assalariado não é a expressão do indivíduo e sim um trabalho penoso para ele sobreviver. O homem, quando trabalha para sobreviver, não se reconhece no seu trabalho, ao contrário, seu trabalho lhe é estranho. $\mathrm{O}$ homem estranha-se à sua atividade, ao produto dessa atividade, ao outro, à natureza e a si próprio. Pior. $\mathrm{O}$ assalariamento implica a transformação do homem em uma coisa, o homem é transformado, convertido, em força de trabalho e, desse modo, é comercializado. O assalariamento é a coisificação do homem.

A base para isso é a existência de propriedade privada dos meios de produção. Ela faz com que os que não têm propriedade sejam obrigados a se assalariarem para sobreviver. Sem alternativa, o assalariamento então é a escravidão do homem ao proprietário dos meios de produção. O Estado é apenas o garantidor dessa situação abominável. Assim, propriedade privada, Estado e mercado, ao contrário de estarem de acordo com uma alegada, com uma suposta natureza do ser humano, na realidade degradam o homem, infelicitam-no, o oprimem.

Se a propriedade privada, o Estado e o mercado, essas instituições burguesas, nada têm a ver com uma alegada natureza 
SOARES, P.de T.L.P. Políticas Públicas: confusão de ideias e/ou ...

humana, aquelas instituições burguesas não são eternas, elas podem ser substituídas por outras. A produção da vida mediante a divisão social do trabalho na forma capitalista, então, pode ser substituída pela divisão social na forma socialista. A dinâmica dessa substituição é dada pela luta de classe, que leva à substituição do trabalho direto pelas máquinas, fazendo com que a aplicação da ciência à produção seja a principal força produtiva, criando o trabalhador coletivo, a inteligência social. O processo de socialização do trabalho corrói as bases do capitalismo.

Se o trabalho direto já não é mais a principal força produtiva, a base do capitalismo, que é exploração do trabalho do outro, fica minada. A teoria do valor perde sentido. A propriedade privada, idem. Mas, se vamos para o socialismo, para um modo de produção da vida consentâneo ao processo de socialização do trabalho, não está garantido. Pode-se caminhar para a barbárie. Vai depender da luta de classe.

Lênin dá outra "martelada" no edifício burguês. A livre competição capitalista, em virtude da superioridade da grande produção, leva ao monopólio. A fase monopólica é uma fase de decomposição e parasitismo do capitalismo. Decomposição, porque o monopólio não tem os mesmos estímulos para o progresso técnico. A condição de monopólio permite maquinações financeiras que compensam a queda da taxa de lucro decorrente da elevação da composição orgânica do capital.

A tecnologia deixa de ser um elemento fundamental da concorrência, como o era na fase competitiva do capitalismo. As enormes escalas de produção impõem a separação entre a propriedade e a gestão, tornando a propriedade privada desnecessária. Parasitismo porque a separação entre propriedade e gestão cria uma camada parasitária que vive dos lucros desse monopólio: oligarquia financeira e aristocracia operária, os personagens dessa nova fase do capitalismo. A fase monopolista é uma fase em que o capitalismo perdeu a capacidade para cumprir as generosas promessas da sua fase competitiva, é a última fase do 
SOARES, P.de T.L.P. Políticas Públicas: confusão de ideias e/ou ...

desenvolvimento do capitalismo. Estamos, portanto, próximos do socialismo ou da barbárie.

Em termos gerais, Marx (Primeiros escritos, A ideologia alemã, Manuscritos econômico-filosóficos, Grundrisse e O capital) e Lenin (Imperialismo: fase superior do capitalismo) passaram a foice e o martelo no discurso burguês. Contudo, o keynesianismo é uma resposta burguesa a essa crítica.

O keynesianismo original reconhece que o futuro é incerto e que há a possibilidade de, mediante mercados com transações regulares, mediante a retenção de ativos líquidos, o capitalista pode não produzir/investir como se espera que ele o faça ou como o governo tenta induzi-lo mediante as políticas econômicas. Ele reconhece que as políticas econômicas tradicionais já não têm tanta potência para estimular a economia. Ele reconhece que o governo precisa defender o presente do medo do futuro e, por isso, precisa planejar, interferindo nas expectativas, e precisa mesmo agir diretamente na economia, revertendo a tendência à depressão. Contra uma visão em que o capitalismo é um sistema que se autoajusta, o keynesianismo diz que o capitalismo é um sistema tendente à depressão.

O keynesianismo, além disso, dá o devido crédito às lutas sociais do início do século. Ele não minimiza a relevância política do sangue derramado nessas lutas, algo que é escondido pelos adeptos da burguesia. Ele reconhece ainda que nem todos se beneficiam do desenvolvimento. Ele sabe que muitos são atropelados por esse desenvolvimento. Ele reconhece que há novos personagens no cenário político que precisam ser reconhecidos como tal. O Estado do Bem-Estar Social é uma tentativa do keynesianismo para administrar a luta de classes, para incorporá-la à dinâmica do sistema, impedindo que ela leve a ações destrutivas por parte da massa.

O keynesianismo, do Keynes e não a vulgaridade em que ele se foi convertido, como enfatizado por Antonio Negri (Keynes and the capitalist Theory of the State), por John Holloway (The Abysm Opens: The Rise and Fall of Keynesianism) e por John Hicks (The 
SOARES, P.de T.L.P. Políticas Públicas: confusão de ideias e/ou ...

crisis in keynesian economics), reconhece que as coisas no capitalismo já não funcionam tão bem como antes e tenta dar uma sobrevida ao capitalismo. O neoliberalismo é uma resposta burguesa tanto aos clássicos/liberalismo, quanto ao marxismoleninismo e ao keynesianismo.

Qual o percurso que preparei para falar a vocês sobre o neoliberalismo? Vou mostrar, agora, como leio Foucault, em $O$ nascimento da biopolítica. Vou começar falando do deslocamento da ênfase, da ênfase na liberdade para a ênfase na pluralidade. Depois vou falar da relação entre a concorrência e o monopólio. Em seguida, vou falar da desvinculação, repito, da desvinculação entre a concorrência e a natureza humana. Só depois de tratar desses três pontos, vou chegar às políticas públicas, que são o tema do evento.

Primeiro ponto, deslocamento de ênfase, da liberdade para a pluralidade.

Foucault chama a atenção para um ponto interessante. $\mathrm{O}$ liberalismo é mais um naturalismo do que um liberalismo: liberdade para a natureza humana expressar-se.

Já o conceito central do neoliberalismo não é o da liberdade, mas sim o da pluralidade. Contra uma percepção unificante ou unificadora da sociedade, contra uma valorização de tudo que tende ao comum, ao coletivo e ao geral, o neoliberalismo propõe o individual, o particular, o local.

É preciso aqui complementar a análise de Foucault sobre o neoliberalismo, chamando a atenção que há, nesse ponto, uma apropriação, pelos neoliberais, da crítica feuerbachiana à dialética, especificamente da discussão do espaço versus o tempo. $\mathrm{Na}$ dialética, diz Feuerbach, só se tem uma dimensão, o tempo. Inicialmente ela enrijece as diferenças, transformando-as em oposição e, em seguida, em contradição. Para depois efetivar a 
SOARES, P.de T.L.P. Políticas Públicas: confusão de ideias e/ou ...

negação superadora, efetivar a passagem para uma nova síntese, para uma nova unidade. Feuerbach diz que, na natureza, não existe superação, que as diferenças nunca são resolvidas na natureza, pois o espaço ajeita e distribui habilmente as diversas partes em seus respectivos lugares, de forma que todos acabam sentindo-se à vontade em seu canto, mantendo inalterado o pluralismo dos particulares.

Nessa linha, o neoliberal diz que o mercado é o locus privilegiado da acomodação da coabitação, do pluralismo.

O neoliberalismo, enfatiza Foucault, critica a ideia de contrato social, pois este, a rigor, não é um contrato e sim o momento em que os indivíduos renunciam ao que os define como particularidade. Um corpo social só é possível e pensável a partir do momento em que uma estrutura substitui a lei da individualidade pela comunidade.

Não posso mais uma vez deixar de ir além de Foucault. Não posso deixar de chamar a atenção para algo muito interessante, inclusive porque muitos dos que se dizem marxistas não sabem, mas esta é uma crítica de Marx que está no que é chamado, de forma até depreciativa, Primeiros Escritos. Marx criticou a igualdade com base nesse tipo de raciocínio.

O que disse Marx nos chamados Primeiros Escritos? Ele disse que a igualdade é uma farsa porque na verdade, no mundo real, um homem difere do outro. Portanto, para se ter um homem igual ao outro, tem que se abstrair do homem real e ter um homem imaginário, uma ficção. A igualdade só é obtida quando o indivíduo real, concreto, abandona-se de si, converte-se numa abstração, em um indivíduo que não é ele. A igualdade é uma ficção.

Sei que todo marxista apoia a igualdade, mas eu leio Marx diferente. Marx diz exatamente o contrário do que diz esse marxismo predominante, um marxismo aburguesado, fetichezado. Marx diz que a gente tem que chegar ao socialismo para que as pessoas possam expressar essas diferenças, diz que o mercado é que nos iguala. Bom, o fato é que os neoliberais, consciente ou 
SOARES, P.de T.L.P. Políticas Públicas: confusão de ideias e/ou ...

inconscientemente, apropriaram-se da crítica de Marx e a apresentaram como sendo deles.

Mas voltemos a Foucault e aos neoliberais. Desenvolvendo essa linha de crítica, eles vão dizer que a ascensão do fascismo e do nazismo não foi uma reação à ascensão do socialismo, como se costuma dizer. Vão dizer que o fascismo e o nazismo são o resultado inevitável das tendências socialistas cristalizadas no planejamento governamental, sufocadoras das liberdades dos indivíduos, castradoras das liberdades humanas. Ou seja, eles dizem querer espaço para todos os indivíduos, espaço para os diferentes coabitarem. Quando se tem um planejamento, uma centralização, mata-se o indivíduo, dizem os neoliberais. $\mathrm{O}$ Planejamento é a negação da pluralidade, a negação do indivíduo, a redução das dimensões espaço e tempo para apenas a dimensão tempo. É a igualação e, consequentemente, a morte da pluralidade.

Então o neoliberal vai ter horror a todo e qualquer planejamento. Qual é o argumento? Sufocador dos planos individuais. Os planos individuais são sagrados. Deixando-se os indivíduos agirem livremente, eles se ajustam, a coletividade se ajusta. Note-se que, diferentemente dos liberais, não se trata de liberdade para a expressão da natureza dos indivíduos, e sim de liberdade para que eles encontrem um meio de coabitar. Esse é o novo fundamento do horror ao planejamento.

$\mathrm{O}$ segundo ponto fundamental da reação neoliberal ao marxismo e ao liberalismo é a relação entre concorrência e monopólio. O monopólio, segundo o neoliberal, não nasce da concorrência, não nasce da lógica econômica. É um corpo estranho à ordem econômica. É fruto da intervenção externa e sem ela não passa de um fenômeno passageiro e sem importância. O neoliberal diz que não só a concorrência não leva ao monopólio, como o monopólio é um fenômeno irrelevante. Sim, o neoliberal diz que o monopólio é um fenômeno irrelevante.

O monopólio, para o neoliberal, é um fenômeno arcaico, concedido por estados soberanos em troca de favores, fruto de arranjos políticos ou de heranças e patentes, criado por economias 
SOARES, P.de T.L.P. Políticas Públicas: confusão de ideias e/ou ...

nacionais e protegido por leis alfandegárias. $\mathrm{O}$ neoliberal reconhece a tendência ao aumento da concentração de capital fixo, mas diz que essa concentração só leva ao monopólio se tiver alguma ajuda externa, pois a constante mudança técnica, a frequente inovação tecnológica, gera novos produtos que eliminam os monopólios já existentes. Se eventualmente surge um monopólio, ele é temporário, porque sempre surgem novas técnicas, novos produtos que o eliminam.

Mais ainda. O monopólio não causa muito estrago, pois ele não tem estímulo para cobrar preços extorsivos, pois isso atrairá concorrentes. Preços extorsivos são um tiro no pé. Isso é uma coisa "fenomenal", fantástica. Eu acho isso um "brinco". Uma esperta operação ideológica. Algo que os clássicos sabiam ser deletério para o capitalismo passa a ser um fenômeno estranho ao capitalismo, passageiro e sem importância. É “interessante" (ressaltem-se as aspas) como gente tão esperta não percebe que o concorrente logo vira monopólio, quando já não nasce monopólio e o que acontece de fato é a substituição de monopólios, a substituição de um monopólio por outro monopólio.

Ora, se a concorrência não se transforma em monopólio, ou quando isso acontece é de forma passageira e sem importância, concluem os neoliberais, o mercado pode ser usado como um regulador econômico social geral, pois é um sistema eficiente de informações, o mais eficiente sistema de informações encontrado pelo homem. O mercado, assim como a propriedade privada e o Estado garantidor dela, na perspectiva neoliberal, é o mais inteligente, o mais eficiente arranjo social já encontrado pelo homem.

O terceiro ponto fundamental da reação neoliberal ao marxismo e ao liberalismo é negar a relação entre a natureza humana e o mercado. A liberdade, para os liberais, era a liberdade para a natureza humana expressar-se. A liberdade, para os neoliberais, é a liberdade para a coabitação dos diferentes. Como, então, organizar essa coabitação, que mecanismo utilizar para tal? O mecanismo, dizem os neoliberais, mais inteligente já encontrado 
SOARES, P.de T.L.P. Políticas Públicas: confusão de ideias e/ou ...

pelo homem é o mercado, pois, ao contrário do que dizem os clássicos e os marxistas, não há tendência para a monopolização e, quando ela acontece, não é importante.

O neoliberalismo, desse modo, promove uma inversão na questão do liberalismo (naturalismo, no dizer de Foucault). A questão deixa de ser: "como encontrar um arranjo que melhor expresse o ser humano?". A questão passa a ser: "como ajustar o ser humano a um arranjo eficiente?". A questão do neoliberalismo é saber como regular o exercício do poder político, com base nos princípios de uma economia de mercado. Como Foucault bem deixou claro, no neoliberalismo o poder enformador, que dá forma à sociedade, é o mercado, é a concorrência e, por conseguinte, a empresa. A forma geral é um jogo de empresas regulado no seu interior por um arranjo jurídico institucional garantido pelo estado.

Qual é a ideia central? A ideia central é o homem-empresa. O que se faz hoje no cotidiano? Todo o seu cotidiano é com base no calculo econômico. Quando se sai com a namorada, você faz conta. Um amigo? Você faz conta se vale a pena tê-lo como tal. Hoje não se tem amigos e sim rede de network. O ser humano é transformado numa empresa, age como se fosse uma empresa, ele dirige a sua vida como dirige uma empresa. A sociedade, ironicamente, torna-se o próprio objeto da intervenção estatal. Uma intervenção radical, multiplicando no interior do corpo social a forma empresa. Fazendo do mercado, da concorrência e da empresa o poder enformador, o poder que dá forma à sociedade. Mais ainda.

Os neoliberais reconhecem que o mercado é um regulador social, mas não é um dado natural, não é algo encontrado no interior da sociedade. Se é assim, dizem os neoliberais, o mercado só funcionará bem se nada perturbá-lo. Daí a constante preocupação neoliberal com a tal da moldura institucional. Ela tem que estar permanentemente sendo recriada. Exatamente porque ela não é natural é que o governo tem de estar permanentemente tomando conta para que ela sobreviva. E se não se mexer no mercado, se limitarmos o governo a cuidar da moldura 
SOARES, P.de T.L.P. Políticas Públicas: confusão de ideias e/ou ...

institucional, aí sim, nesse caso, fluirá uma lógica diferenciadora como a da natureza. O fluir da desigualdade, o fluir da diferenciação, explica a obsessão com a não intervenção no mercado: deixar fluir os planos individuais.

Entende-se, por conseguinte, a obsessão com a inflação zero. A inflação mascara os movimentos de preços relativos que informam a escassez de produção/investimentos, de um lado e o excesso de produção/investimentos, do outro lado. Onde há excesso de produção/investimentos, o preço cai; onde há falta de produção/investimentos, o preço sobe. A inflação é deletéria porque dificulta a percepção desses movimentos dos preços relativos.

A Lei de Responsabilidade Fiscal e a autonomia do Banco Central, tão defendida pelos neoliberais tupiniquins, estão exatamente neste contexto, o de impedir que o governo intervenha na economia, provocando movimentos indesejados de preços relativos, atrapalhando a percepção dos movimentos de preços relativos, frustrando planos individuais.

O neoliberalismo surge propondo um novo capitalismo, diz Foucault. Quer instalar uma nova ordem social que é economicamente regulada pela economia de mercado. O instrumento disso é o estado de direito e a regra da lei. O estado de direito definido como estado em que os atos do poder público não poderão intervir ou adquirir valor, se não forem enquadrados na lei, se não forem limitados previamente pela lei. O governo não pode se meter na vida da sociedade, ele tem que deixar o mercado organizá-la.

Nenhuma intervenção do governo terá uma linha específica ou fim específico. $O$ governo não pode promover o desenvolvimento, não pode fomentar a saúde, não pode aumentar a educação. O governo não pode fazer nada. $\mathrm{O}$ governo não pode ter nenhum objetivo. A única coisa que o governo pode fazer é cuidar do aparato em que o mercado vai funcionar, em que a concorrência vai regular a sociedade. A única intervenção do estado na ordem econômica ocorrerá pelo estabelecimento de princípios formais. 
SOARES, P.de T.L.P. Políticas Públicas: confusão de ideias e/ou ...

O governo não pode ter um plano. Ele não pode dizer, propor, agir para que a distância entre as rendas diminua. Ele não pode agir para aumentar ou reduzir esse ou aquele tipo de consumo. Jamais poderá intervir com o objetivo de promover o desenvolvimento econômico, pois essa é uma decisão dos indivíduos atuando livremente no mercado. A lei não pode estar no bojo da concepção econômica. A lei tem que ser concebida a priori. As regras não podem ser alteradas em razão dos efeitos que produziram. Deixe que o mercado, funcionando livremente, faça a correção, o ajuste, solucione os problemas. Escola pública, universidade pública? Jamais! O mercado cuidará disso. Saúde pública? Jamais! O mercado cuidará disso.

$* * *$

Para o keynesiano faz sentido haver política social intervencionista. Para o neoliberal isso é um anátema. Só faz sentido se ter políticas públicas, ou seja, a intervenção limitar-se á moldura institucional, jamais haver intervenção direta. A política social, na sociedade neoliberal, não pode ser um contrapeso ao desenvolvimento econômico, pois os mecanismos de mercado não são obtidos por fenômenos de igualação e sim por um jogo de diferenciações. É preciso deixar fluir o jogo da desigualdade. Não se pode tentar mexer na desigualdade porque se muda a regra do jogo. Não se pode pedir à sociedade inteira atuar para redimir os indivíduos contra riscos, sejam eles individuais, como doença ou acidente, sejam eles coletivos, como intempéries ou catástrofes naturais. Isso é um plano, é uma afronta à liberdade individual, um atentado à pluralidade.

Então, política social intervencionista, buscando a igualdade e proteção da sociedade contra riscos, não faz nenhum sentido na perspectiva neoliberal. A maneira de se garantir que os planos individuais não serão afetados não é mediante uma cobertura social, e sim mediante a concessão a cada indivíduo de um espaço 
SOARES, P.de T.L.P. Políticas Públicas: confusão de ideias e/ou ...

econômico em que lhe seja possível assumir para si os riscos e enfrentá-los. A política social, na perspectiva neoliberal, tem que se limitar a garantir que os mecanismos concorrenciais possam exercer o seu papel de regulador e organizador da sociedade. A política social tem que se limitar a garantir um espaço econômico que permita ao indivíduo enfrentar os riscos na forma como ele escolher, segundo seu plano individual.

Se é assim, na perspectiva neoliberal só há duas coisas que servem como política social: o crescimento econômico e o Imposto de Renda Negativo, que é a tal Renda Mínima ou, "tupiniquinamente", o Bolsa-Família. Num país de desinformados, de pouca instrução inclusive nas camadas superiores, por causa da equivocada imagem de esquerdista do Suplicy, há a errônea crença generalizada de que o Renda Mínima é um projeto da esquerda. Todo mundo pensa que o Renda Mínima/Bolsa-Família é uma proposta de esquerda. Mas ela é uma proposta do neoliberalismo norte-americano.

A ideia é simples. Dá-se dinheiro para o cara e ele assume os riscos, o governo não assume mais nada. Se o cara usa o dinheiro para drogar-se, em vez de fazer poupança para sobreviver na velhice, o governo não se mete. Se chegar à velhice e ele morrer de fome, foi uma escolha dele e ninguém tem que se meter nisso, ele que arque com as consequências das decisões passadas. O que acontecer com esse sujeito vai sinalizar para as pessoas as consequências do ato, e elas então, com mais informações disponíveis, decidirão como proceder: gastar imediatamente ou poupar para o futuro. Se, mesmo conscientes das consequências, elas gastarem o dinheiro com drogas em vez de pouparem, tem-se que respeitar as decisões individuais. Se o indivíduo resolver usar o dinheiro para queimar fumo e cheirar cocaína, em vez de fazer um seguro-saúde, vale a mesma coisa. A sociedade não tem que arcar com os custos das decisões individuais erradas.

Nessa perspectiva, o governo fornecer previdência e saúde estimula a indisciplina, a irresponsabilidade social, dizem os neoliberais. Essa sempre foi uma crítica dos neoliberais aos 
SOARES, P.de T.L.P. Políticas Públicas: confusão de ideias e/ou ...

keynesianos. Uma crítica que "tupiniquinamente" é mascarada na discussão sobre o déficit da previdência e nas críticas (legítimas) à prestação de serviços de saúde pelo governo.

No caso "tupiniquim", as privatizações da saúde e da previdência, para os neoliberais, não são apenas um caso de oportunidade de lucro, são um modo para acabar com a indisciplina social. A desobediência ao patrão é maior porque não há "enforcement" dos atos dos indivíduos. Se eu tenho saúde, educação e previdência garantidas pelo governo, não me submeto tão facilmente, tão docilmente, ao patrão, não aceito tanto esforço no trabalho. Aliás, a reação ideológica tupiniquim ao BolsaFamília diz exatamente isto: "Ela estimula a vagabundagem, o pessoal agora está cheio de direitos, quer salários absurdo". É certo que para isso o que contribuiu mesmo foi o esforço de formalização do emprego e a pressão sobre o mercado de trabalho, mas não se pode esperar muito da nossa elite em termos de análise. O horror do neoliberal ao keynesianismo não é uma mera questão técnica, é acima de tudo política: como enfrentar a luta de classes.

Mas o que fazer quando no mundo real o fato concreto é o crescimento econômico não possibilitar ao indivíduo as condições para ele próprio assumir os riscos sociais?

$\mathrm{O}$ apoio não pode ser em forma de consumo coletivo, porque não vale a pena dar às pessoas mais ricas a possibilidade de participar do consumo coletivo de saúde e educação, uma vez que elas são as mais capazes para arcar com esses benefícios. Por exemplo, é preciso acabar com a universidade pública e o ensino público, porque há muito rico que poderia pagar e que não está pagando. $\mathrm{O}$ apoio só pode ser dado às pessoas que, seja a título definitivo, como o idoso ou o deficiente, seja a título passageiro, momentâneo, como o desempregado, não podem assumir os riscos sociais e ter um padrão de consumo que a sociedade considera decente. $\mathrm{O}$ apoio que for dado tem que ser socialmente eficaz sem ser economicamente perturbador. A sugestão do neoliberalismo norte-americano foi o imposto de Renda Negativo, ou Renda Mínima ou "tupiniquinamente”, Bolsa-Família. 
SOARES, P.de T.L.P. Políticas Públicas: confusão de ideias e/ou ...

Abaixo de uma margem mínima de renda, será concedido um benefício, em forma de pagamento, que permita àqueles indivíduos atingirem certo patamar de consumo considerado o mínimo aceitável. Eles então vão ao mercado e demandam os bens e serviços necessários para sua sobrevivência no curto e no longo prazo. Abandona-se a ideia de que a sociedade deve a cada um dos indivíduos serviços básicos, como saúde e educação. O governo dá o dinheiro, mas retira-se do fornecimento dos bens e serviços, deixa isso para o mercado fazer.

O que é, então, política social, ou melhor, política pública no ambiente neoliberal? É a negação, é a morte, da rede de proteção social. Não é demais repetir. Política pública é a negação da rede de proteção social. Bom, com o que foi exposto, já podemos chegar a uma conclusão baseada na perspectiva marxista-leninistalukacsiana-debordiana. Vou bem além do que Foucault disse sobre o neoliberalismo.

O neoliberalismo é um rompimento com o liberalismo, porque inverte a questão: em vez de buscar um arranjo social para melhor expressar a natureza do homem, ele busca ajustar a sociedade a um dado arranjo institucional suposto ser o mais inteligente e eficiente jamais concebido. Com a inversão da questão central, passando-se de como encontrar um arranjo que melhor expresse a natureza do homem para como ajustar o homem ao um arranjo supostamente, alegadamente, o mais inteligente arranjo já encontrado pelo homem, desnuda-se toda a operação ideológica do neoliberalismo.

O neoliberalismo faz um veemente discurso a favor do individual, do indivíduo, do ser humano, mas na realidade o que ele quer é dar liberdade para adaptar o ser humano à regra do mercado, para transformá-lo quase que em uma empresa. $\mathrm{O}$ neoliberalismo é uma farsa, porque faz o elogio do indivíduo, mas na prática o transforma em uma coisa, ao exigir que ele se comporte em todas as dimensões da vida como se estivesse gerindo uma empresa, exige que o homem se comporte como uma empresa. 
SOARES, P.de T.L.P. Políticas Públicas: confusão de ideias e/ou ...

O neoliberalismo elogia o homem, mas o faz para transformá-lo em uma coisa/empresa.

O neoliberalismo é um discurso hipócrita e mentiroso, como Marx fala que é todo discurso burguês. Uma farsa porque se está falando do individual, sacralizando o indivíduo, mas na realidade se está transformando esse indivíduo em uma empresa, em uma coisa. É a coisificação da vida, tão enfatizada por Marx e por Lukács (História e consciência de classe). O neoliberalismo é a ideologia da culminação da transformação do homem em coisa, é a ideologia da cosificação do homem.

Há, também, obviamente, uma veneração do mercado como organizador da sociedade. É um endeusamento do mercado. Um Deus que toma conta da vida dos indivíduos, em todas as suas dimensões, como lamentado pelo teólogo Harvey Cox, em Deus Mercado: vivendo uma nova dispensação. Só que é um Deus que não cria indivíduos, como pensa Cox e sim cria coisas/empresas. O mercado, para os neoliberais, é como um Deus, pois tudo pode, tudo sabe e está em todo lugar, é onipotente, onisciente, onipresente. $\mathrm{O}$ indivíduo não tem mais emoção, ele faz contas, ajusta emoções em razão das contas que faz. Os amigos dele são em razão das possibilidades de network. O trabalho passa a ser suportável se houver possibilidades de ascensão social e econômica. Tudo que o indivíduo faz e pensa é na perspectiva de subir na vida, de ter mais bens materiais, sua felicidade está nos bens materiais. Para isso, ele está o tempo todo fazendo conta. O fetichismo tomou conta da vida das pessoas. O raciocínio econômico é tido como sinônimo da razão, como o ápice da razão. Deus e Mercado são substitutos na determinação da vida dos homens, reclama o teólogo Harvey Cox.

Marx, já nos chamados Primeiros Escritos, seguindo Feuerbach, chamava a atenção para a inversão entre o sujeito e o predicado, base da alienação e do fetichismo. O neoliberalismo inverte a relação sujeito-predicado, transforma o sujeito em predicado do seu predicado. A empresa é um apêndice do sujeito, 
SOARES, P.de T.L.P. Políticas Públicas: confusão de ideias e/ou ...

mas este se transforma em um apêndice da empresa. $\mathrm{O}$ indivíduo transforma-se em um apêndice do seu apêndice.

O homem, no neoliberalismo, comporta-se como coisa, como empresa, e é essa coisa, a empresa, que se comporta como humano. Não é por acaso que a gente se refere às coisas como se elas pensassem, agissem, como se elas tivessem vida. Referimonos à empresa, ao mercado, ao governo, como se eles fossem humanos. Referimo-nos a eles como se se fossem humanos. Atribuímos a eles uma lógica, uma força, à qual temos que nos adaptar, em vez de as adaptarmos aos nossos interesses. O homem foi reduzido a uma única dimensão, a dimensão de fazer conta: custo-benefício. Portanto, não faz nada que não seja relacionado ao custo-benefício, não há nenhuma outra relação fora do custobenefício. Chamar isso de ser humano é um engano.

Marx chamava a atenção para a farsa burguesa, que era enfatizar o geral, o social para legitimar o particular e o privado. Marx chamava a atenção para a ênfase no abstrato e no desprezo pelo concreto, para a ênfase no geral em detrimento do particular, para a ênfase no teórico e na desconsideração da prática.

$\mathrm{O}$ indivíduo que o neoliberalismo enfatiza não é o indivíduo real, concreto e sim o indivíduo abstrato, teórico. O neoliberalismo, por inocência ou por oportunismo, trata de um indivíduo teórico, ignorando que na realidade há indivíduos com propriedade e indivíduos sem propriedade e que, portanto, os planos individuais que serão afetados pela ação do governo são os planos dos indivíduos proprietários. A preocupação, no discurso, é com o indivíduo em geral, mas como esse indivíduo geral só existe no reino da ideia, na imaginação do neoliberal, a preocupação verdadeira, de fato, na prática é com o indivíduo proprietário. Liberdade para o proprietário dos meios de produção, esse o lema verdadeiro do neoliberalismo.

Lênin, no famoso Imperialismo: fase superior do capitalismo (ensaio popular), enfatiza que a fase monopólica do capitalismo, uma fase de acentuada concentração e centralização da produção e da riqueza, é uma fase em que está acentuada a 
SOARES, P.de T.L.P. Políticas Públicas: confusão de ideias e/ou ...

contradição entre o caráter social de produção e o caráter privado da apropriação. A fase monopolista do capitalismo é uma fase superior dessa contradição e não do capitalismo, como as leituras ligeiras concluem.

O que o neoliberalismo faz na fase em que o caráter social da produção está acentuado, em que a teia de relações sociais está desenvolvidíssima? Ele enfatiza o particular, o privado. Então o neoliberal é um delirante, um sonhador, pois em uma fase em que o característico, o típico, é o caráter social da produção da vida, ele sonha com o indivíduo, com o particular em separado do geral, como se isso fosse possível, uma vez que o mercado faz exatamente o contrário. O neoliberalismo é um retrocesso do ponto de vista histórico-filosófico, pois é o elogio da alienação, da coisificação e do fetichismo.

A tal política pública pode ser vista como a síntese disso. Do ponto de vista neoliberal, a política pública é substituta da rede de proteção social. Não é demais repetir: política pública é a negação da rede de proteção social, é a culminação da entrega da vida ao comando do mercado. E a tal da esquerda não se deu conta disso.

Pior, fica defendendo políticas públicas, quando deveria estar defendendo a rede de proteção social. Eu fico me perguntando como e por que a esquerda defende tanto as tais políticas públicas.

Não se trata de mera confusão de ideias, de simples erros conceituais, de novo nome para coisas antigas. Marx disse, no $A$ ideologia alemã, que a linguagem é a expressão na prática da consciência. A predominância do termo política pública mostra a imposição à esquerda do linguajar neoliberal. Expressa uma derrota política e ideológica da esquerda. A esquerda já perdeu a disputa, porque quem dá o tom é a direita. Aliás, hoje, até a esquerda concorda que falar em intervenção direta do governo é um pecado, uma coisa "velha", "arcaica". A própria esquerda abomina a intervenção do governo, critica a exagerada presença do governo na vida das pessoas. A tal da esquerda "comprou" as teses da direita neoliberal. A esquerda já perdeu a disputa ideológica. 
SOARES, P.de T.L.P. Políticas Públicas: confusão de ideias e/ou ...

Definitivamente não me identifico com essa esquerda. Dessa vitória ideológica da direita não se dá porque ela é um monstro todo poderoso. Ela se dá porque encontrou um terreno fértil para atuar. E agora, ligando esse ponto da derrota ideológica da esquerda à critica ao PT, começo a encerrar esta exposição.

O PT não é um partido de esquerda. O PT é um partido da aristocracia operária, não tem nada a ver com a esquerda. O PT nasceu na ideologia pequeno burguesa radical, como a dos populistas russos, a quem Lenin tanto combateu. O PT converteuse no partido da aristocracia operária, a quem Lênin tanto odiava, como tanto horror tinha. Lênin passou a vida brigando inicialmente com os populistas e depois com a aristocracia operária. Inicialmente populista (à la populistas russos) e depois aristocracia operária, delirando ser de esquerda. O PT atuou e aceitou o debate no campo burguês.

O que é o mensalão, caso emblemático, senão uma subordinação às regras burguesas? A burguesia compra o apoio político todo dia, todo dia. O que é o acordo para compor o governo? Loteiam-se os postos no governo entre os apoiadores e financiadores. A tradição é o executivo chamar seu aliado, parceiro/correligionário e estabelecer: você cuida da Secretaria X ou da empresa Y e comanda a coisa tipo 70/30. Nessa condição, o correligionário o aliado, é sócio, é parceiro. Minoritário, mas sócio. Mas aí veio um tucano mineiro e inventou um negócio "genial" (ressaltem-se as aspas). Chamou o parceiro para cuidar da Secretaria X, mas em vez de ele arrecadar, quem arrecadaria era o Executivo, e o aliado receberia os $30 \%$ tradicionais. O PT, degradado ideologicamente, noviço nas estruturas do poder, inocentemente achou que isso era uma grande invenção. Deu no que deu!

Por que deu errado? Esse parceiro deixou de ser sócio para ser empregado. Se o PT tivesse lido Marx com atenção, saberia que o assalariamento é uma "merda" e não teria convertido parceiros em empregados. $\mathrm{O}$ mensalão inverteu a lógica da corrupção/compra de apoio, e todo mundo foi contra. Mais ainda, o 
SOARES, P.de T.L.P. Políticas Públicas: confusão de ideias e/ou ...

PT delirou que chegando ao poder podia jogar como a elite sempre jogou. Neste país, branco de olho azul pode fazer a burrada que for, agora pobre que quer se meter na mesma raia do rico, aí não, aí é uma coisa horrorosa. Essa "gentalha", essa "mulambada" vai querer roubar como nós? Não! Ela não vai poder fazer um negócio desses, pois esse é um negócio da elite, uma exclusividade da elite. A turma do mensalão é a única turma presa na história deste país por roubar e corromper o poder. Ela, a rigor, não foi presa por corrupção, mas por tentar inverter a lógica da corrupção da elite.

Veja-se o negócio da Petrobrás agora, outro caso emblemático. O caso da Petrobrás é uma coisa "fantástica", porque sempre se comentou sobre uma deslavada corrupção na empresa. $\mathrm{O}$ Paulo Roberto Costa era funcionário da Petrobrás. Só agora ele virou ladrão? Não se tem a roubalheira no setor público se não tiver a conivência dos empregados. Lá, tudo alguém tem que ler e assinar. Não há, portanto, corrupção sem a conivência dos empregados que leram, assinaram e deram andamento dentro da empresa/secretaria/ministério.

Como a aristocracia operária atua? Ela vê a roubalheira dos políticos e fica quieta, até ajuda a roubalheira, facilita toda a roubalheira. Aá quando chega a hora do dissídio ela cobra. Aí o que os executivos fazem para calar os empregados, para abafar a gritaria? Concedem benefícios sociais/trabalhistas inacreditáveis em relação ao mercado. Então, na realidade a aristocracia operária é sócia do político corrupto. O político corrupto põe o dinheiro no bolso (na Suíça, nos paraísos fiscais, etc.), usa para financiar o partido, a campanha política. A aristocracia operária recebe benefícios inacreditáveis em relação ao mercado e diz que ele é fruto da luta sindical.

Essa é uma velha história, mas o carimbo de corrupto ficou só para o PT! Aliás, o carimbo de o maior corrupto da história deste país: "Nunca se roubou tanto!", dizem os incautos e os espertos.

Qual o contexto da passagem do PT de populista russo para a aristocracia operária? O contexto da derrocada da URSS e da 
SOARES, P.de T.L.P. Políticas Públicas: confusão de ideias e/ou ...

queda do muro de Berlim, sem uma compreensão adequada da parte da esquerda para o evento. Isso provou uma derrocada ideológica, uma conversão não raro fervorosa ao neoliberalismo. Subordinado ideologicamente, o PT não chegou ao poder com novas práticas, com a recusa às práticas burguesas. Ele chega ao poder pensando que agora fazia parte da elite a quem sempre se opusera. Pior... ele reforça valores burgueses.

O PT constrói sua própria derrota quando fica divulgando que transformou todo mundo em classe média, que gerou um sistema de mercado com oportunidades para todos. Quando ele faz esse discurso da transformação social, ele faz com que aquele "pobre", "burro", desinformado, ignorante, que melhorou de vida comece a se sentir rico e aí, como é praxe entre os ricos neste país com forte herança colonial-escravista, comece a ter desprezo e até mesmo raiva do pobre. $\mathrm{O}$ pobre que virou classe média pensa como esta e passa a não gostar de pobre. $\mathrm{O}$ cara trabalha no mercado financeiro, enche a conta de dinheiro, mas tem raiva do Lula, porque não percebe que o cassino financeiro foi estimulado pelo PT. Ele, com a incultura que o caracteriza, acha que ficou rico porque é brilhante. Outro vende para uma loja de varejo que vende para pobre. Essa rede de loja expande-se enormemente, por causa das políticas do Lula/Dilma. Mas o cara pensa que ganhou dinheiro exclusivamente com sua competência. Ambos acham que não precisam do governo, que melhoraram de vida exclusivamente porque são bons e se esforçaram. Limitados intelectualmente não percebem que ganharam dinheiro por causa do cassino financeiro e da distribuição de renda promovidos pelo governo petista.

Com a mente estreita típica do pequeno burguês, não percebem o contexto em que vivem, não veem além do próprio umbigo. Ambos aderiram aos valores burgueses e têm ódio ao PT, ao Lula, ao Bolsa-Família. Aliás, agora reclamam que o BolsaFamília encareceu a mão-de-obra que eles contratam e estimulam a vagabundagem. A fragorosa derrota da Dilma em São Paulo é a expressão disto: “do ódio de classe". É certo que São Paulo é um mar de cana, e esse setor não se deu bem com a Dilma, mas o 
SOARES, P.de T.L.P. Políticas Públicas: confusão de ideias e/ou ...

aspecto ideológico é fundamental para entender a derrota da Dilma no mais "republicano à la EUA" dos estados brasileiros.

Não bastasse isso, a Dilma comprou uma briga internacional com o imperialismo e o fez sem base política para tal. A massa não foi mobilizada. A elite adora Miami, sonha com o "fake" de Las Vegas e vive das patentes que vêm dos EUA.

Parece que a Dilma está repetindo os tempos de luta armada, em que se acreditava que as vanguardas transformariam o país.

Vamos pegar o caso dos caças suecos. A aeronáutica lá atrás, na época de Fernando Henrique Cardoso, queria comprar o caça russo, mas o EUA disse que não podia. Passaram-se os anos, e o FHC não desobedeceu aos EUA. O Lula também não teve coragem de solucionar esse problema. Ele flertou com a França, mas os EUA falaram que não podia e ele também não os desobedeceu. Vem então a Dona Dilma e, quando ela descobre que está sendo espionada, resolve dar o troco e comprar o caça sueco. Inaceitável para os EUA. Mais ainda. Toda a política externa dos EUA é feita com base no petróleo, como Lenin ensinou sobre a importância das fontes de matérias-primas para o domínio do mundo. Esmagar a Rússia continua sendo uma obsessão dos EUA, que não aceitam uma potência concorrente no cenário internacional. Aqui se pensa que a Rússia não é nada, mas estamos em um país em que a elite se pauta pela revista Veja e pela TV Globo. Dilma alinha-se com os BRICS e vai explorar o Pré-Sal com os chineses, adversários dos EUA no cenário internacional. Absolutamente inaceitável para os EUA. Mais ainda. Dilma não apoia a política imperialista dos EUA disfarçada em combate ao terror.

A política de "Regime Change" volta-se para o Brasil, especificamente para derrubar Dilma. É maluquice cogitar que o caso Petrobrás tem algo a ver com a espionagem dos EUA na Petrobrás e que foi repassada aos aliados dos EUA na Polícia Federal? Alguém desconhece a influência das polícias norteamericanas nas polícias de todos os países da América Latina? Os aliados internos aos EUA passaram a movimentar-se intensamente, 
SOARES, P.de T.L.P. Políticas Públicas: confusão de ideias e/ou ...

com gana, com ódio. Volta à carga o tradicional "mar de lama" usado contra os governos populares desde Getúlio Vargas. Aliás, uma arma fundamental em todos os países em que a política de "Regime Change" operou, como mostra Luiz Alberto Moniz Bandeira, em A segunda guerra-fria: geopolítica e dimensão estratégica dos Estados Unidos - das rebeliões na Eurásia à África do Norte e ao Oriente Médio. Um ataque hipócrita, sim hipócrita de moralismo, assaltou a uma parte considerável dos eleitores de direita. Votaram no que roubava "menos". Isso é hipocrisia. Talvez eles nem percebam quão hipócrita isso é. $\mathrm{O}$ moralismo como arma política. $\mathrm{O}$ moralismo como espetáculo debordiano (A sociedade do espetáculo).

O medo da alegada "comunização" está de volta. É preciso salvar a democracia derrotando o PT, dizem eles. Vinte anos de PSDB em São Paulo é democrático, mas doze anos de PT no governo federal é um projeto ditatorial. Burrice ou esperteza? Qualquer argumento vale para tentar impedir o projeto "popular" petista de continuidade no poder. Parece que voltamos a 1964: contra o comunismo e contra a corrupção. A história se repete como tragédia ou como farsa.

A Dilma e o PT tornam-se o grande satã a ser combatido, destruído. Com que força política ela conta para se defender? Do jeito que está, a derrota dela me parece inevitável. Os 35\% de votos no Aécio mostram o sucesso da política de "Regime Change", para derrubar os governos não alinhados aos EUA. Quantos por cento da Marina vão para Dilma?

Se o PT não tiver uma mudança radical na propaganda, acentuando a luta dos ricos contra os pobres, se ele continuar tentando ganhar eleitores com um discurso burguês de benefícios para todos, certamente vai dar Aécio no segundo turno. Aliás, mesmo com mudança, não sei se dará tempo para reverter o 
SOARES, P.de T.L.P. Políticas Públicas: confusão de ideias e/ou ...

quadro. Não é uma questão de marketing político e sim de política real mesmo. É uma questão do modo como o PT será visto pelo eleitorado. É uma questão de se o PT ainda tem credibilidade para fazer um discurso diferente do que tem feito até agora.

\section{Referências bibliográficas}

COX, Harvey. O mercado como Deus: vivendo a nova dispensação. mimeo. Departamento de Economia da Universidade Federal Fluminense. Rio de Janeiro: 1999.

DEBORD, Guy. A Sociedade do Espetáculo. Rio de Janeiro: Contraponto, 1997.

FOUCAULT, Michel. Nascimento da Biopolítica. Curso no Collège de France (1978-1979). São Paulo: Martins Fontes, 2008.

HICKS, John. The Crisis in Keynesian Economics. Oxford: Basil Blackwell, 1974.

HOBBES, Thomas de Malmesbury. Leviatã ou Matéria, forma e poder de um Estado eclesiástico e civil. Tradução de João Paulo Monteiro e Maria Beatriz Nizza da Silva, Editora Abril: São Paulo, 1974 (coleção Os Pensadores).

HOLLOWA, J. The Abyss Opens: The Rise and Fall of Keynesianism", in W. Bonefeld, J. Holloway (eds). Global Capital, National State and the Politics of Money. London: Macmillan, 1995. p. 7-34.

LENIN, V. I. O imperialismo, fase superior do capitalismo. São Paulo: Alfa Omega, 1986.

LUKÁCS, G. História e consciência de classe: Estudos sobre a dialética marxista. São Paulo: Martins Fontes, 2003. 
SOARES, P.de T.L.P. Políticas Públicas: confusão de ideias e/ou ...

KEYNES, J. M. Teoria geral do emprego, do juro e da moeda. Tradução Mario R. da Cruz. 2. ed. São Paulo: Nova Cultural, 1985.

MARX, Karl. Manuscritos econômico-filosóficos. $2^{\mathrm{a}}$. Reimpressão. São Paulo: Boitempo, 2008.

. A Ideologia Alemã. São Paulo: Boitempo, 2007.

. Grundrisse. São Paulo: Boitempo: 2011.

O Capital. Crítica da Economia Política. Livros I, II e III. São Paulo: Nova Cultural, 1996.

NEGRI, Antonio. Keynes and the Capitalist Theory of the State post-1929. In: Revolution Retrieved: Selected Writings on Marx, Keynes, Capitalist Crisis \& New Social Subjects 196783. London: Red Notes, 1988. p. 9-42.

SMITH, Adam. A Riqueza das Nações: investigação sobre sua natureza e suas causas. São Paulo: Nova Cultural, 1988.

Recebido em Novembro de 2014 Aceito em Dezembro de 2014 